\title{
Intellectual Property and Standardisation: Key Aspects for an Innovative India
}

\author{
Begoña Glez Otero ${ }^{1}$, Sheetal Chopra ${ }^{2}$ \\ ${ }^{1}$ EU Business School Group, Munich, Germany \\ ${ }^{2}$ Ericsson, Gurgaon, India
}

Email address:

b.otero@euruni.edu (B. G. Otero), sheetal.chopra@ericsson.com (S. Chopra)

To cite this article:

Begoña Glez Otero, Sheetal Chopra. Intellectual Property and Standardisation: Key Aspects for an Innovative India. Science, Technology \& Public Policy. Vol. 3, No. 2, 2019, pp. 14-22. doi: 10.11648/j.stpp.20190302.12

Received: July 5, 2019; Accepted: October 16, 2019; Published: November 17, 2019

\begin{abstract}
The telecom sector has been a pivotal force behind India's digital transformation. Surge in data consumption and rapid adoption of new technologies continue to redefine connectivity and engagement dynamics in India. As the largest data consumer and the second largest smartphone market, India is carving out a new digital identity globally. At the same time such a digital transformation has been brought by innovative companies who wish to be compensated for their efforts, often via licensing. The first part of this paper will explain the impact of standardization on the Indian market. The second part will focus on the key role of an effective patent enforcement system in balancing standardisation contributors and implementers' interests. On this regard, the paper analyses the changing patent landscape in India. It follows a brief review of the Indian jurisprudence relating to patents essential to a technical standard. Third, the paper will identify some of the main strengths and obstacles of the patent litigation system in this particular field, including some concrete proposals or suggestions for improvement in the latter. Finally, the paper will sketch some general conclusions.
\end{abstract}

Keywords: Standards, Standard Essential Patent, Patent Litigation, FRAND Licensing

\section{Introduction}

Globally, there are 7.8 billion mobile subscribers. Nearly $15 \%$ of the mobile subscribers are from India. In 2018, $45 \%$ of the 300 million net additions have been Indians [1]. The telecom sector has been a pivotal force behind India's digital transformation. Surge in data consumption and rapid adoption of new technologies continue to redefine connectivity and engagement dynamics in India. As the largest data consumer and the second largest smartphone market, India is carving out a new digital identity globally [2].

As of June 2018, India has the second largest telecom network in the world, with around 1.20 billion subscribers by December 2018 [3]. Reasons for such a paramount revolution are, among others, the increasing broadband and internet penetration, exponential data uptake, the Government's focus on digitalization and the increasing trend of technology adoption across industries [4].

Four main factors that make India different from already established markets are:
1. India has the lowest call charges in the world, and the largest growth of subscribers, due to the diligence of the telecom operators on the one hand and the lowest mobile termination charges (MTC) rates [5] coupled with the calling party pays (CPP) regime [6]. Both were introduced by the Telecom Regulatory Authority of India (TRAI) [7].

2. India's digital profile and footprint is one of the fastest growing in the world, and the data economy and digital technologies and services are no longer the prerogative of the privileged few; over 200 million Indians regularly used social media in 2017. And over 200 million Indians took to mobile banking and digital payments. At the current pace of digitization and digitalization, it is estimated that India's digital economy has the potential to reach one trillion USD by 2025 [8].

3. Along with strong consumer demand, are the liberal and reformist policies of the Government of India. The government has enabled easy market access to telecom equipment and a fair and proactive regulatory 
framework that has ensured availability of telecom services to consumer at affordable prices. The deregulation of Foreign Direct Investment (FDI) norms has made the sector one of the fastest growing and a top five employment opportunity generator in the country [9].

4. The Indian Government released the National Digital Communication Policy in 2018 that encourages developing patents essential to the standards in the field of digital telecommunication technologies [10], besides creating a high level $5 \mathrm{G}$ committee.

\section{The Impact of Standardisation on the Indian Market}

Technological innovation and broadband connectivity are considered as a major stimulus for economic growth [11]. Thus, the Indian telecommunications revolution would be likely to generate new growth avenues, boost industrial productivity and have the potential to transform the socioeconomic fabric of the country. To achieve this revolution, during the latest Celebration of 50 Years of World Telecommunication and Information Society Day (WTISD19), in May 2019, the Indian DoT, Ministry of Communications encouraged companies to invest their time and resources to develop standards for the industry for its overall growth and expansion [12]. This is because standardisation has played and will play a central role in this regard, same as it has for enabling $5 \mathrm{G}$ adoption. For instance, at a global level, a study in 2014 showed that the mobile value chain, thanks to standardisation, had a return of over USD 3 trillion and generated 11 million jobs [13].

Standards set out norms or guidelines that enable devices from different manufacturers to interoperate with each other, that is to communicate and share information with each other while assuring high performance. Cellular standards are created by different companies that cooperate in Standard Developing Organisations (SDOs). The role of SDOs is to coordinate and facilitate a standard setting and development process with the involvement of various stakeholders. The absence of standardisation bodies in India was strongly felt in the telecom sector. With the launch of the Telecom Standards Development Society (TSDSI) on November 7, 2013, operating as of January 2014, Indian companies were given the opportunity to contribute to the development of global telecommunications standards, becoming innovators instead of purely implementers [14].

The standardisation process at SDOs takes place via multiple candidate technologies proposed and contributed by companies (service providers, manufacturers) and other stakeholders (academia, industry associations, test labs, startups, governmental departments). This diverse membership implies that participants have different interests and business models [15]. Then, within the standardisation process, the best contributions, selected by consensus and based on their technical merits, are incorporated into the standard. The cutting-edge technology contributed to the standardisation process, often resulting from large $R \& D$ investments, is normally protected by patents [16]. As a result, these patents could end up becoming standard essential patents (SEPs). This means that to implement a standard, it will be necessary to use that patented technological feature in order to sell a product or provide a service which complies with the standard.

It is not new to say that patents, as exclusive property rights, confer the right to exclude others. However, in light of incorporation of their patented technologies into the standards, SDOs encourage the patent owners to offer access to these standard essential patents on Fair, Reasonable and Non-discriminatory (FRAND) [17] terms and conditions in return of a guarantee that the Intellectual Property Right (IPR) holders are adequately and fairly rewarded for the use of their IPRs in the implementation of the technical specifications [18].

The precise terms of the licensing are left to the parties to agree upon, in good faith, and in accordance with prevalent industry practice [19].

The working balance of interests and incentives is what makes collaborative standardisation as a process of superior efficiency if compared to de facto standardisation. FRAND licensing is vital for maintaining a predictable and rewarding structure of returns that provides powerful incentives for contribution of technologies and implementation of standards. On the one hand, licensing revenue from FRAND royalties, by ensuring that patent holders reap a fair reward for their contributions, provides strong incentives for leading innovators to contribute the best available technologies to the standardisation process [20]. On the other hand, the FRAND commitment ensures that standards will remain accessible to all.

Additionally, standardisation brings important and perceptible benefits to consumer welfare, by providing not only interoperable products, but greater product choice with high performance products at increasingly lower prices. Indeed, 4G technology can transfer data 12,000 times faster than $2 \mathrm{G}$ technology, the average mobile subscriber cost per megabyte decreased $99 \%$ between 2005 and 2013, and smartphones are now available for around \$40 [21].

All in all, there is substantial evidence that SDOs in mobile telecommunications have performed well. The performance of telecommunication networks has increased dramatically in all important respects: in capacity, data rates, reliability, latency and security. The upcoming $5 \mathrm{G}$ will be key for autonomous vehicles, remote surgery, factory workflow automation, and billions of connected devices [22]. Added to that, empirical evidence suggests that patents declared as potentially standard essential at SDOs are of higher quality and receive roughly three times more citations than their nonSEP counterparts [23]. All these factors are particularly important for countries such as India or China, where the consumer-reported value of mobile exceeds $40 \%$ of average income [24]. 


\section{The Key Role of an Effective Patent Enforcement in Balancing Standardisation Interests}

Patent protection drives innovation by incentivising investment in $\mathrm{R} \& \mathrm{D}$ [25]. The protection of the exclusive patent right also allows for the disclosure of the invention, fostering further innovation [26]. However, patent law as an incentive for innovation, and in interaction with competition law, as a means to promote follow-on research, have to be coordinated and balanced with the interests of the parties involved in licensing, namely those contributing to the standard and those using it. Efficient licensing of intellectual property rights (IPR) requires a successful balancing of the incentives to invest in innovation against the benefits for the economy at large of a wide diffusion of knowledge. The licensing of SEPs is however prone to market failures such as free-riding, i.e. when implementers incorporate the SEP holder's innovative technology in their products or services without compensating him [27]. The various forms of market failure can result in barriers obstructing the efficient licensing of SEPs and can thus hinder the realization of the economic and societal benefits of the affected standards [28].

Although in the case of standard essential patents, both patent litigation and competition law procedures are key for understanding this complex sector, this paper will focus only on patent litigation. The main reasons for this are space limitation, the shortage of Indian literature analysing the role of an effective patent enforcement system to balance interests amid standardisation contributors and implementers, and the fact that the applicability of the Competition Act 2002 to FRAND disputes is presently under judicial scrutiny [29]. To start this exploration, the paper will analyse the changing patent landscape in India. It will continue with a brief review of the Indian jurisprudence on SEP related cases. Then, it will identify the obstacles and strengths of the patent litigation system in this particular field; including a number of proposals for improving the aforementioned balanced.

\subsection{The Changing Patent Landscape in India}

Since 2005 the Indian courts have witnessed an increase in patent litigation. Kumar and Sawhney argue this was an obvious consequence of putting a product patents regime for pharmaceuticals and agrochemicals in place. Another fact that may have contributed to the rise of patent litigation is that during 2005 India made the necessary amendments to its patent law to comply with TRIPs Agreement [30].

Kumar and Sawhney also point out, as indicated in figure 1 , that while pharmaceutical cases have lessened, there has been a recent increase in patent litigation in the fields of electronics and information and communications technology [31].

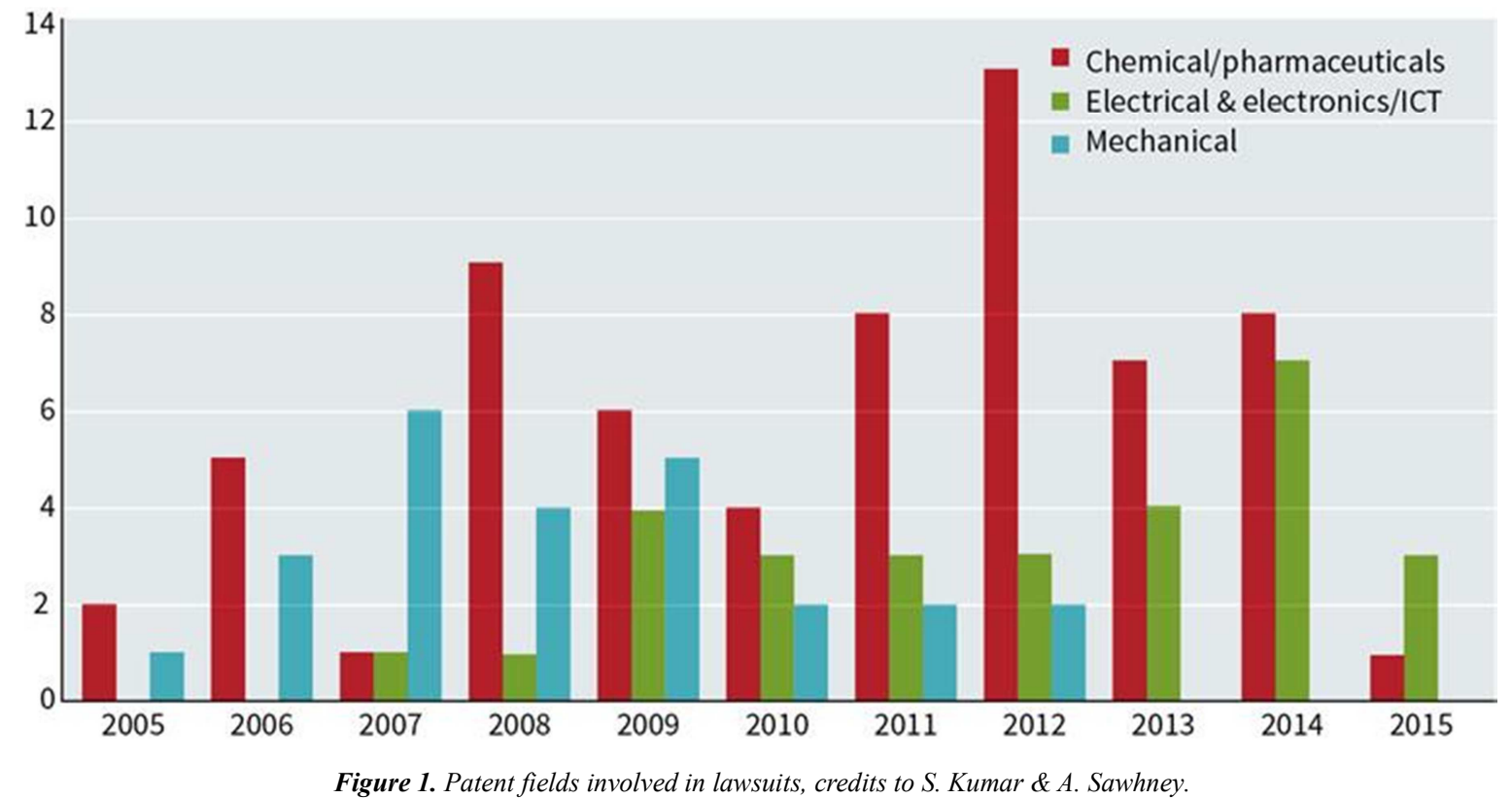

In the past few years, India has also made positive efforts to position itself as an attractive market for investments. In 2016, the Indian government adopted an ambitious national intellectual property rights policy. India has also put in place several new initiatives such as "Make in India", aimed at transforming India into a global design and manufacturing hub. The "Startup India" program, another initiative by the Indian government, incentivizes and supports domestic startups. There have also been efforts to improve the country's ranking in the Global Innovation Index. With regard to the "ease of doing business" India's position has witnessed an impressive jump of 53 places in the past 2 years. According to the World Bank's 2019 report, India is now ranked on the $77^{\text {th }}$ out of 190 countries [32].

\subsection{Brief Review of Standard Essential Patent Related Cases in India}

India has become one of the world's largest mobile markets, as the result of embracing standardisation [33]. 
Since the standardised technologies are often the result of massive R\&D investments, SDOs guarantee that innovative companies, providers of such technology, will be fairly compensated for their efforts, often via licensing.

When SEP holders first approached smartphone companies in India, these companies were not all familiar with the value of intellectual property and FRAND licensing for SEPs. Indian companies have undergone a steep learning curve, jumping from the distribution business to the mobile business. Thus, India has seen a related rise in standard essential patent licensing and litigation.

The first SEP litigation cases in India were initiated by Philips in 2009, when they sued two local companies for selling assembled DVD players, which contained chipsets allegedly infringing a Philips Indian patent covering a "decoding device for converting a modulated signal to a series of m-bit information words". Both suits were consolidated by the Delhi High Court [34]. The patent expired in 2015. Due to the lengthy process and the expiration of the patent, an injunction was no longer possible.

Moreover, the fact that, in SEP cases such as in Philips' case, alleged infringers may raise an antitrust complaint causing an overlap between the jurisdictions of the civil court authorities and the competition authorities, led to further delay in the process.

The Philips matter was finally decided, after a long wait of 9 years, leading to India's first judgment on SEP litigation, on July 12, 2018. Although the decision was well-reasoned, this example shows the extraordinary length of time SEP cases take to progress through the Indian court system.

Starting in 2013, Ericsson became involved in some cases against several companies before the Delhi High Court. What these and the other above mentioned cases had in common are the requests by the patent holder for interim relief on its FRAND-assured SEPs, seeking damages and the upholding of the company's practices of licensing under its FRAND commitment [35].

Also, in November 2013, Vringo Infrastructure Inc., which had acquired over 120 patent families relating to telecommunications and infrastructure from Nokia, filed two suits against ZTE and its Indian subsidiary ZTE Telecom India [36]. One of those suits was for infringement of SEPs Vringo had acquired from Nokia. Yet, the novelty of this case is that for the first time since litigation over SEP patents started in India, the Delhi High Court agreed to appoint a "scientific advisor" from a list of experts to advise the court about the technical and scientific evidence placed on record [37].

\subsection{An Analysis Based on FRAND Case law}

Based on the existing jurisprudence, there are some lessons to be taken from the current practices of the Delhi High Court, that could serve as a lesson for other Indian courts that may need to deal with this kind of patent infringement case and from which certain improvements towards a more efficient litigation system could be driven.

\subsubsection{Well-reasoned Decisions}

Although SEP litigation is quite new for Indian courts, the Delhi High Court has showed a high level of skill and reasoning in the substantiation of its decisions, including addressing controversial topics such as injunctions.

In forming its decisions, the Court has sometimes looked to other jurisdictions that have more experience dealing with these issues, such as the U.S. and the European Union.

An example of a case where the Indian courts have referenced foreign jurisprudence is the 2009 Philips case, resolved in 2018. When the Court had to assess damages for patent infringement, applied the US Court of Appeals for the Federal Circuit's methodology in Commonwealth Scientific and Industrial Research Organization (CSIRO) vs. CISCO Systems, Inc., relying on informal negotiations between the parties to set a rate.

Also, as noted earlier, the Court has incorporated a wellknown practice around the globe: to bring experts to provide testimony in complex SEP litigation matters. Even more, in one of Ericsson's cases [38], the Court used the so-called hot tub method. That is, the allowance of expert witnesses to offer their opinions in the form of a discussion.

Moreover, the Court has been concordant with current judicial and regulatory trends across the world, by granting injunctions against unwilling licensees, by using the value of a downstream product as a royalty base and by relying on comparable license to derive the FRAND royalty rate [39].

Lastly, on the question of jurisdictional overlapping, the Delhi High Court was asked to decide on the jurisdiction of the Competition Commission of India (CCI) when a patent infringement case under civil litigation was pending [40]. The central question here was whether complaining on grounds of abuse of dominant position to the CCI, while the patent infringement case was prior filed and ongoing [41], could be seen as strategy to further delay the litigation process. The Court suggested that the Patent Act ousts the jurisdiction of the CCI and hence both the acts have parallel application.

\subsubsection{The Importance of Injunctions Against Unwilling Licensees}

An important element in the decisions related to injunctions in FRAND cases has been the (un)willingness of licensees to negotiate FRAND terms.

In 2016, the Department of Industrial Policy and Promotion (DIPP) published a discussion paper on SEPs and their availability on FRAND terms, in order to solicit public opinion on a suitable policy framework [42]. The policy document included a section on the judicial approach towards SEPs and their availability on FRAND terms, both before the CCI and the Delhi High Court. It also included a series of questions on key issues for resolution, inviting views from all concerned stakeholders. In the particular matter of SEPs and injunctions, the question was if given the commitment to grant a FRAND license, should injunctive relief be generally available or restricted. The topic might be new to India, but it has been broadly discussed in many other jurisdictions, 
irrespective of its maturity. For instance, in the US, injunctions for patent infringement have been reduced drastically following the Supreme Court case eBay $v$. MercExchange [43]. This has led to an imbalance in favour of implementers which has been heavily criticized by the Department of Justice [44]. In Europe, there is more certainty, since the Court of Justice of the European Court in the landmark case Huawei v. ZTE [45] clarified that in order for the SEP holder and the implementer to obtain or avoid an injunction respectively, the parties should follow certain steps provided by the Court [46].

In the case of India, Section 108 (1) of the Patent Act of 1970 provides remedies against unauthorized use of patents in general through injunctions [47]. The framework designed by the Indian patent regime allows the court to decide whether an injunction is appropriate in view of any applicable FRAND commitment and provides an important check on the ability of SEP holders to obtain injunctions. The provision does not confer any special category to SEPs by depriving patentees from any right enshrined by the Parliament, in accordance with legal standards in more mature jurisdictions such as European or North American countries [48].

Yet, it has been argued that the Indian judiciary has dealt with this matter in its own way regarding not the granting of an interim injunctive relief but lifting it too fast [49]. For instance, in some of the cases where an injunction was granted in favour of Ericsson [50], the court noted that an exclusion order was appropriate where the implementer-licensee:

1. refused to accept a FRAND license;

2. demanded terms outside an SEP owner's FRAND commitment; or

3. did not engage in a negotiation in good faith to determine FRAND terms.

All in all, it seems that Indian courts have recognised the importance of balance in protecting against both hold-up [51] by SEP holders and hold-out [52] by implementers.

However, the court was ready to lift the injunction, with the consent of parties, if the implementers deposited the (court determined) royalty payment during the pendency of the litigation.

Moreover, the court's willingness to determine the interim royalty rates, is now set as the current standard in telecoms SEP battles. Thus, if a SEP holder can show before an Indian court that a defendant is prima facie an unwilling license and is only interested in using the patented technologies for free, the court may exercise its discretionary power to grant an injunction in favour of plaintiff. The implementers, however, have the option of entering into an interim arrangement with the SEP holders to avoid the injunction by depositing an interim royalty payment as determined by the court. The interim arrangements are rather nuanced and a more balanced form of determination that obliges both parties to act in good faith. In practice, the implementer (who has been found to be a potential infringer prima facie) has to submit interim royalties to the court or to the plaintiff. If an implementer is directed to deposit royalties by the SEP holder, a counter bank guarantee would have to be submitted by the SEP holder against the payment of such royalties.

However, different from jurisdictions more accustomed to the licensing of intellectual property rights, it appears that most of the defendants in standard essential patent infringement cases in India have not met their obligation to respond diligently and/or in good faith to a SEP holder's offer. One reason may be, as indicated above, that many of these Indian companies were purely focused on the distribution business and they are still going under a steep learning curve to understand intellectual property rights management, now that they have jumped to the mobile phones business.

Accordingly, a patent holder needs to have the comfort to rely on effective injunctive relief remedies against unwilling licensees so that these have no incentive to hold-out, which is not always the case. Ideally, an ex parte injunction should not be lifted if the SEP holder can establish at the time of starting the case that the implementer has consistently used dilatory tactics in the FRAND negotiations.

\subsubsection{Procedural Litigation Time Management}

In India, there are no specialised courts for patent infringement actions; therefore, there are no specialised patent judges as such. Additionally, there is a surprisingly high number of changes of roster of judges which could significantly and unnecessarily extend the length of the procedures [53].

On top of that, given that courts in India have millions of pending case [54] with judicial vacancies waiting to be filled, it is no surprise that patent cases in India take years to resolve.

Therefore, for improvement of time efficiency the timelines set by the court need to be strictly adhered to and litigation subterfuges of granting adjournments must be summarily rejected. On this regard, it could serve as an example the US case management conference system in patent cases, where the judge, in agreement with the parties, sets a timeline with strict deadlines that are enforced by the courts. This gives certainty and predictability to the parties and helps in both, the efficiency and the time management of the overall process, even if the judge would be replaced [55].

One other proposal could be to look at one of the most efficient patent litigation systems in the world: Germany. Germany has a bifurcated system, with different courts for the infringement and validity sides of litigation. In most cases the first-instance infringement decision is issued within eight to fifteen months, while on the validity side the average timeframe is twenty-five months. If an infringement court is convinced that the patent in suit will highly likely be nullified in the parallel invalidity proceedings, it will stay its proceedings until the validity decision has been rendered. Even non-final infringement decisions are usually immediately enforceable if the requisite security is provided. Once the court has confirmed infringement, the period leading up to the validity ruling is often the best time to negotiate a settlement. 
The costs of patent litigation in Germany are usually much lower than those in the United States or the United Kingdom. In particular, there is no US-style pre-trial discovery or jury trials, and inspection proceedings are neither mandatory nor frequently used. Oral hearings (in comparison to trials) typically last hours, rather than several days.

Further, the specialised German courts hearing patent cases handle more than $60 \%$ of all patent cases in Europe; they might be thus a good mirror to look up to.

Last but not least, it is important to emphasise the respect of the principle of legal certainty. This is a fundamental principle recognised by most jurisdictions around the world. In the sphere of litigation this principle translates into judges being consistent, respecting procedural deadlines and applying exceptions such as granting extensions during the procedure to the parties in a restrictive manner. This way, parties know what to expect and reasonably know how long it might take for a case to progress in court, how much would it cost. Thus, the principle of legal certainty gives parties the ability to regulate their conduct in court and trust the litigation system.

\section{Conclusions}

It is clear that the adoption of FRAND licensing and a standardisation process based on transparency, impartiality, openness and consensus has led the Indian market to open up, removing many entry barriers. On the other hand, as jurisprudence on SEPs evolves in India and a supportive legal framework develops to better support IP commercialization and enforcement, India will create further confidence for global investors. Investments in India will flourish in a balanced and welcoming IP environment. With balanced IPR policies, India could become further engaged and participating in developing technology standards with a similar development as we have seen in other countries. For instance, if we look at reports showing the patent distribution for top patent holders of 4G-LTE patents published in 2012, we identify companies from different countries among the main contributors, which have been particularly careful of fostering IP [56] (see figure 2).

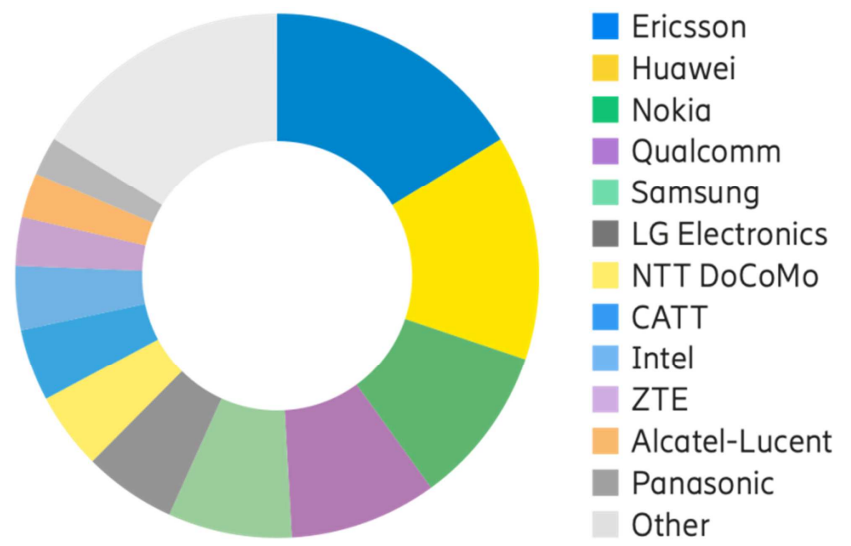

Figure 2. Multi-node 4G, 5G share of approved contributions in RAN1 and RAN2 [57].
India could become a global competitor in technology innovation if adopting strategies to increase IP awareness, support the inventors and foster standardisation. There is already a huge pool of Indian engineers and universities that can be part of it. The Internet of Things and 5G, also imply plenty of opportunities for new use cases and technologies evolving. India should thus continue to respect global practice followed related to licensing of SEPs as it is proven that FRAND is in general pro-competitive and courts are well positioned to address the specific circumstances of each individual case. FRAND licensing in India has enabled entry of new businesses, increased manufacturing, larger consumer demand for standardised products, falling product prices, economies of scale, etc.

At the patent litigation level, it is crucial to encourage the parties to engage in good-faith negotiations and induce them to reach mutually agreeable terms in an expedient manner. The Indian courts have already taken steps in this direction, but more can be done toward a more effective enforcement of IP rights to provide more legal certainty. This in turn would increase the ease of doing business and play a key role in attracting more foreign direct investment

In order to achieve these goals some recommendations have been provided in this paper. For instance, India could consider establishing specialised IP courts. Also, the country would benefit from the shortening of the litigation process, e.g. by setting and respecting an order schedule, like the U.S. practice shows.

Today, effective and timely enforcement of standard essential patents is still one of the major challenges facing the Indian telecom revolution. Still, the potential from Indian industry to become contributors instead of purely implementers is enormous. The sky is the limit.

\section{Acknowledgements}

Begoña Glez. Otero wishes to gratefully acknowledge the financial support from Ericsson. The views expressed herein are those of the authors alone and do not necessarily represent Ericsson's views.

\section{References}

[1] EY, CII, "\#Broadband 2022 - Unlocking a trillion dollar digital economy" (2018) available at: https://www.ey.com/Publication/vwLUAssets/ey-broadband2022-unlocking-a-trillion-dollar-digital-economy/\$FILE/eybroadband-2022-unlocking-a-trillion-dollar-digitaleconomy.pdf; last accessed May 23, 2019.

[2] Ernst \& Young LLP, "Propelling India to a trillion-dollar digital economy. Implementation roadmap to NDCP 2018" (2018) at foreword by Shri Manoj Sinha, available at: https://www.ey.com/Publication/vwLUAssets/ey-propellingindia-to-a-trillion-dollar-digital-economy/\$FILE/eypropelling-india-to-a-trillion-dollar-digital-economy.pdf; last accessed May 23, 2019) 
[3] IBEF Report "Growth of Telecom Industry in India Infographic-” (2019) available at: https://www.ibef.org/industry/telecommunications/infographic ; last accessed May 23, 2019.

[4] See: S. Chopra, P. Chawla, "Innovation, Growth and Intellectual Property: A Study of the Indian Telecom Sector and the Way Forward" (2018) Journal of National Law University Delhi 5 (1) 40-60; IBEF report, Telecommunications, January 2019, available at: www.ibef.org; last accessed May 23, 2019; GSM Association, "The Mobile Economy Asia Pacific" (2018) available https://www.gsmaintelligence.com/research/?file=28401018963d 766ca37d014fa9cbffb1\&download; last accessed May 23, 2019)

[5] MTC are the charges which one telecommunications operator charges to another for terminating calls on its network. The India Telecommunications Authority cut significantly mobile termination chargers already in 2017. See: https://www.thehindu.com/business/Industry/trai-cuts-mobiletermination-charges-57-eyes-waiver-by-

20/article19715998.ece; last accessed May 23, 2019.

[6] "Calling party pays" or CPP is a payment model in cellular markets, that states that the total cost of a call is borne by the caller and not the receiver.

[7] V. Sridhar, The Telecom Revolution in India: Technology, Regulation and Policy, (2012) OUP.

[8] Indian National Digital Communications Policy 2018, available at: http://dot.gov.in/sites/default/files/EnglishPolicyNDCP.pdf last accessed May 23, 2019.

[9] IBEF, “Telecoms Industry in India”, March 2019, available at: https://www.ibef.org/industry/telecommunications.aspx; last accessed May 23, 2019. Moreover, since 2014, the department of Commerce has been engaged in organizing various meetings concerning the achievement of an optimal regulatory ecosystem for standardisation, with the goal of positioning standards as a key driver of all economic activities in the sector; enhance competitiveness of Indian goods and services in domestic and international markets; or providing a level playing field to domestic industry. See: Ministry of Commerce and Industry, Department of Commerce, Indian National Strategy for Standardisation (INSS), 2018, available at: https://commerce.gov.in/writereaddata/uploadedfile/MOC_63 6655449469105249_INSS_Booklet_2018.pdf; last accessed May 23, 2019.

[10] See Indian National Digital Communications Policy 2018, available at: http://dot.gov.in/sites/default/files/EnglishPolicyNDCP.pdf, p. 13, last accessed May 23, 2019.

[11] See: ITU, "Impact of Broadband on the economy" (2012) Broadband Series, available at: https://www.itu.int/ITUD/treg/broadband/ITU-BB-Reports_Impact-of-Broadband-onthe-Economy.pdf; last accessed May 23, 2019; EY, CII, "\#Broadband 2022 - Unlocking a trillion dollar digital economy" (2018) available at: https://www.ey.com/Publication/vwLUAssets/ey-broadband2022-unlocking-a-trillion-dollar-digital-economy/\$FILE/eybroadband-2022-unlocking-a-trillion-dollar-digitaleconomy.pdf; last accessed May 23, 2019.

[12] A. Prakash, Speech: "Telecom Sector Needs Standardisation. Industry should not shy away from investing its time \& resources to evolve standards", National Apex Chamber, No. PR-18, May 17, 2019, New Delhi, available at: https://www.phdcci.in/press_releases/telecom-sector-needs- standardisation-industry-should-not-shy-away-from-investingits-time-resources-to-evolve-standards-anshu-prakash/; last accessed May 23, 2019.

[13] J. Bezerra et al., Boston Consulting Group, "The Mobile Revolution and How Mobile Technologies Derive TrillionDollar Economy" (2015) January 15, available at: https://www.bcg.com/publications/2015/telecommunicationstechnology-industries-the-mobile-revolution.aspx; last accessed May 23, 2019

[14] TSDSI is public-private partnership entity run by participation of all the stakeholders together, the government, service providers, manufacturers, researchers and vendors. See https://tsdsi.in/about/; last accessed May 23, 2019.

[15] A. Layne-Farrar, "Business Models and the Standard Setting Process"; available at: http://papers.ssrn.com/sol3/papers.cfm?abstract_id=1718065 (2010), at 1, last accessed May 23, 2019)

[16] For instance, Boston Consulting Group estimates that to achieve 5G standard mobile players will need to invest approximately $\$ 4$ trillion in R\&D and capital expenditures by 2020. See: "The Mobile Revolution 2015", available at: https://www.bcg.com/publications/2015/telecommunicationstechnology-industries-the-mobile-revolution.aspx; last accessed May 23, 2019.

[17] RAND is also used as synonymous of FRAND in the US.

[18] TSDSI IPR Policy, clause 1.3, available at https://members.tsdsi.in/index.php/s/6rxhutadeGUAVKd\#pdfv iewer

[19] G. Richard, "Competition Policy for Industry Standards" at 3, available at: https://papers.ssrn.com/sol3/Papers.cfm?abstract_id=2273333, last accessed May 23, 2019.

[20] R. Bekkers, A. Updegrove, "A study of IPR policies and practices of a representative group of Standards Setting Organizations worldwide" (2012) at 6. Available at: http://papers.ssrn.com/sol3/papers.cfm?abstract_id=2333445; last accessed May 23, 2019.

[21] Boston Consulting Group, "The mobile revolution-how mobile technologies drive a trillion dollar impact" (2015) at 3 and $7 . \quad$ Available at: https://www.bcgperspectives.com/content/articles/telecommun ications_technology_business_transformation_mobile_revolut ion; last accessed May 23, 2019.

[22] C. Tapia, "Who are the creators of the 5G standard?" (2019) The Trademark Lawyer, at 2.

[23] M. Rysman, T. Simcoe, "Patents and the performance of voluntary standard setting organizations" (2008) Manag Sci 54: 1923 .

[24] Ibid. at 4.

[25] See among others: D. L. Burk, M. A. Lemley, "Policy Levers in Patent Law" (2003) 89 VA. L. REV., 1575; R. Falvey, N. Foster, "The Role of Intellectual Property Rights in Technology Transfer and Economic Growth: Theory and Evidence" (2006) United Nations Industrial Development Organization, Vienna, at available at: https://www.unido.org/sites/default/files/200904/Role_of_intellectual_property_rights_in_technology_transf er_and_economic_growth_0.pdf; last accessed May 23, 2019. 
[26] See among others, J. C. Fromer "Patent Disclosure" (2009) 94 Iowa LR at 539, available at: https://www.fhmuenster.de/bibliothek/downloads/Fromer_PatentDiscloser.pd f; last accessed May 23, 2019.

[27] On free riding and its impact see the decision Continental $T$. V., Inc. v. GTE Sylvania, Inc., 433 U.S. 36, 55 (1977); A. Künzler, "Restoring Consumer Sovereignty: How Markets Manipulate Us and what the Law can Do About It" (2017) OUP, at 45.

[28] ECSIP Consortium, "Patents and standards: A modern framework for IPR-based standardisation" (2014) Study prepared for the European Commission Directorate-General for Enterprise and Industry.

[29] See OECD document "Licensing of IP Rights and competition law - Note by India" (DAF/COMP/WD (2019) 4) submitted on June 6, 2019. Available at https://one.oecd.org/document/DAF/COMP/WD(2019)4/en/p df; last accessed May 23, 2019.

[30] S. Basheer, "India's Tryst with Trips: The Patents (Amendment) Act 2005" IJLT, Vol. 1, 2005. Available at SSRN: https://ssrn.com/abstract=764066; last accessed May 23, 2019.

[31] S. Kumar, A. Sawhney, "The patent litigation environment in India", IAM Media, September 12, 2016, available at: https://www.iam-media.com/patent-litigation-environmentindia; last accessed May 23, 2019.

[32] World Bank Group Flagship Report "Doing Business 2019. Training for Reform" (2019) available at: https://www.worldbank.org/content/dam/doingBusiness/media /Annual-Reports/English/DB2019-report_web-version.pdf; last accessed May 23, 2019.

[33] In the last 10 years some SDOs have emerged in India in various sectors. There are five key SDOs, namely the Telecom Standard Development Society of India (TSDSI), Telecommunication Engineering Centre (TEC), Bureau of Indian Standards (BIS), the Global ICT Standardisation for Telecommunications in India (DOSTI).

[34] Koniklijke Philips N. V. vs Bhagirathi Electronics \& others CS (OS) 1082/2009); Koninklijke Philips N. V. vs Rajesh Bansal (Mangalam Technology) (CS (COMM) 24/2016) Delhi High Court.

[35] Six cases took place over the period of 2013 to 2016: Telefonaktiebolaget LM Ericsson (Publ) vs. Mercury Electronics and Anr. (2013) Delhi High Court, CS (OS) 442/2013; Telefonaktiebolaget LM Ericsson (PUBL) vs. GIONEE COMMUNICATION EQUIPMENT CO. LTD. and ANR (2013), CS (OS) No. 2010/2013; Telefonaktiebolaget LM Ericsson vs. Intex Technologies (India), Indiankanoon.org (2014) Delhi High Court, CS (OS) 1045/2014; Telefonaktiebolaget LM Ericsson (Publ) vs. Xiaomi Technology and Ors (2014) Delhi High Court, CS (OS) 3775/2014; Telefonaktiebolaget LM Ericsson (PUBL) vs. Lava International Ltd. (2015) Delhi High Court, CS (OS) 764/2015; Telefonaktiebolaget LM Ericsson (PUBL) vs. M/S BEST IT WORLD (INDIA) PRIVATE LIMITED (iBall) (2015), CS (OS) 2501/2015; Lava International Limited vs Telefonaktiebolaget LM Ericsson (PUB) (2016), CM (APPL.) $23769 / 2016$.

[36] Vringo Infrastructure Inc and Anr. vs. Xu Dejun and Ors. (2013) Delhi High Court, CS (OS) 2168/2013.

[37] Vringo Infrastructure Inc and Anr. vs. Xu Dejun and Ors,
FAO (OS) 573/2013, CAV. 1141/2013, C. M. APPL. 19754/2013 and 19755/2013, December 12, 2013, para (ii): "It is agreed that besides framing issues, learned Single Judge would, in exercise of powers conferred under Section 115 of the Patents Act, appoint a scientific advisor to apprise the Court about the technical and scientific evidence brought on the record. The appointment of the scientific advisor shall be from amongst the list of experts."

[38] See above: Telefonaktiebolaget LM Ericsson vs. Intex Technologies (India), Indiankanoon.org (2014) Delhi High Court, CS (OS) 1045/2014. The Court has used this tool during the appeal proceedings. Also, more recently in the Micromax vs, Telefonaktiebolaget LM Ericsson (2019) pronounced on April 23, Delhi High Court.

[39] J. G. Sidak, "FRAND in India: The Delhi High Court's emerging jurisprudence on royalties for standard-essential patents" (2015) JIPLP, vol. 10, no. 8 at 601.

[40] Telefonaktiebolaget LM Ericsson (Publ) v. Competition Commission of India, Case W. P. (C) 464/2014 \& CM Nos. 911/2014 \& 915/2014 and W. P. (C) 1006/2014 \& CM Nos. 2037/2014 \& 2040/2014 (Mar. 30, 2016).

[41] Micromax, Intex and IBall complaint against Ericsson with the CCI, alleging, among other, that the licensing rates were exorbitant, and thus an abuse of Ericsson's dominant position. See: Micromax Informatics Ltd. v. Telefonaktiebolaget LM Ericsson, Case No. 50/2013, Competition Commission of India (12 November 2013), available at http://infojustice.org/wpcontent/uploads/2013/12/CCI-Case-no-50-2013.pdf (last accessed may 23, 2019); Intex Techs. (India) Ltd. v. Telefonaktiebolaget LM Ericsson, Case No. 76 of 2013,\} 6, Competition Commission of India (16 January 2014); Best IT World (India) Private Ltd. v. Telefonaktiebolaget LM Ericsson, Case No. 4 of 2015, Competition Commission of India (12 May 2015), available at http://www.cci.gov.in/sites/default/files/042015_0.pdf (last accessed may 23, 2019).

[42] Government of India, Department of Industrial Policy and Promotion, Ministry of Commerce \& Industry "Discussion Paper on Standard Essential Patents and Their Availability of FRAND Terms", March 1, 2016, available at: http://www.ipindia.nic.in/writereaddata/Portal/News/196_1_st andardEssentialPaper_01March2016_1_.pdf; last accessed May 23, 2019.

[43] eBay Inc. v. MercExchange, L. L. C., 547 U.S. 388 (2006). For a comment on the case see: K. Gupta, J. P. Kesan, "Studying the impact of eBay on injunctive relief in patent cases" (2016) University of Illinois College of Law Legal Studies Research Paper No. 17-03; available at: https://papers.ssrn.com/sol3/papers.cfm?abstract_id=2816701; last accessed May 23, 2019.

[44] See Speech by AAG Makran Delrahim at the $19^{\text {th }}$ Annual Berkeley-Standford Advanced Patent Law Institute, December 7, 2018; available at: https://www.justice.gov/opa/speech/assistant-attorney-generalmakan-delrahim-delivers-remarks-19th-annual-berkeleystanford; last accessed May 23, 2019.

[45] Judgment of 16 July 2015, Huawei Technologies Co. Ltd v ZTE Corp. and ZTE Deutschland GmbH, C-170/13, ECLI: EU: C: 2015: 477. 
[46] For a detailed analysis of the case and the guidelines see: C. Tapia, S. Makris, "Negotiating Licenses for FRANDaccessible Standard Essential Patents in Europe after Huawei v. ZTE: Guidance from National Courts", Managing IP, May 4, 2018. A very up-to-date database including summaries rendered after the Huawei v. ZTE case in key European countries, together with a national courts guidance on licensing negotiation for SEPs can be found at: https://caselaw.4ipcouncil.com/; last accessed May 23, 2019.

[47] Section 108 (1): The reliefs which a court may grant in any suit for infringement include an injunction (subject to such terms, if any, as the court thinks fit) and, at the option of the plaintiff, either damages or an account of profits.

[48] See for European law, among others L. Tochtermann, "Injunctions in European Patent Law", 4IPCouncil Research Paper, 2019, available at: https://www.4ipcouncil.com/application/files/3115/5784/6445/ L._Tochtermann_Injunctions_in_European_Patent_Law.pdf; last accessed May 23, 2019; For the US: J. Contreras, "Injunctive Relief in U.S. Patent Cases", in R. Sikorski (ed.) Injunctions in Patent Law, 2016.

[49] Remfry \& Sagar, "Injunctive relief in SEP litigation: what makes sense in India?” (2017), Lexology, October 12.

[50] In particular, the injunctions sought against Micromax, Intex, Xiaomi and Lava.

[51] In the context of patent licensing, to hold-up refers to a situation where a patent holder seeks increased licensing fees because the patent is essential to a standard. For further information on hold-up see, among others: A. Galetovic, S. Haber, R. Levine, "An Empirical Examination of Patent Holdup" (2015) Journal of Competition Law and Economics, OUP, vol. 11 (3), 549-578.

[52] In the context of patent licensing, to reverse hold-up or holdout refers to a situation where a patent holder instead of being over-compensated, is in fact under-compensated by being forced to accept royalties that are lower than the value of the contribution of their technologies to a standard. For a detailed study of this and other situations arising in standard patent licensing see: V. Angwenyi, "Hold-up, Hold-out and F/RAND: The quest for balance" (2017) JIPLP vol. 12, issue 12, 10121023.

[53] There could be several factors behind the transfer of judges reflected in the "Memorandum Showing The Procedure For Appointment And Transfer Of Chief Justices And Judges Of High Courts", mainly to avoid any kind of potential unfair treatment. For instance, a transfer to another High Court occurs when a judge is appointed as Chief Justice. Also, when a lawyer from the bar is appointed as judge or when a judge is promoted to a High Court. In the event of a complain of corruption which does not lead automatically to impeachment, the judge accused is also transferred to another High Court.

[54] See for instance: https://thediplomat.com/2016/04/30-millionpending-cases-fixing-indias-overburdened-judiciary/; and: https://www.businesstoday.in/current/economy-politics/3-3crore-cases-pending-indian-courts-pendency-figure-highestcji-dipak-misra/story/279664.html (last accessed May 23, 2019).

[55] For a brief overview of case management conference see "Case Management Conference Law and Legal Definition", available at: https://definitions.uslegal.com/c/casemanagement-conference/ (last accessed May 23, 2019). Also: https://sasklawcourts.ca/images/documents/Provincial_Court/ Small_Claims/SC_Case_Management_Conference_Info.pdf (last accessed Maȳ 23, 2019).

[56] See iRunway, "Patent \& Landscape Analysis of 4G-LTE technology" (2012) at 9, available at: https://www.irunway.com/images/pdf/iRunway\%20$\% 20$ Patent $\% 20 \& \% 20$ Landscape $\% 20$ Analysis $\% 20$ of $\% 204 \mathrm{G}-$ LTE.pdf; last accessed May 23, 2019. The top 5 are Samsung, Qualcomm, Panasonic Corporation and Inter Digital.

[57] Estimating the future 5G patent landscape, October 2018, available at: https://www.ericsson.com/en/patents/estimatingthe-future-5g-patentlandscape; last accessed May 23, 2019. 